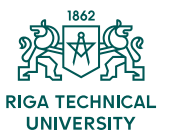

\title{
A REVIEW OF PRECAST CONCRETE PAVEMENT TECHNOLOGY
}

\author{
AMEEN SYED*, RANJAN SONPAROTE \\ Applied Mechanics Department, Visvesvaraya National Institute \\ of Technology, Nagpur, India
}

Received 18 September 2019; accepted 19 February 2020

\begin{abstract}
Precast concrete pavement (PCP) has proven itself to be one of the most efficient methods for repair and replacement of concrete pavement, as well as for construction of new pavement in the areas of heavy traffic. The application of PCP ensures fast construction of concrete pavement without compromising the quality of concrete. This paper provides a brief of various types of PCP that have been used worldwide and their application in the repair of damaged pavement, continuous construction of pavement, Airfield application and temporary pavement construction. It further discusses critical aspects of PCP that require careful analysis prior to its field implementation. The paper specially focuses on panel dimensioning, load transfer mechanism, lifting arrangement, stacking arrangement, transportation and base preparation for PCP. Suitability of different types of PCP for varying site conditions has been discussed. Innovative developments related to PCP and the future scope of this technology have also been discussed.
\end{abstract}

Keywords: pavement repair, precast concrete pavement (PCP), precast construction, prestressed pavement, prestressed precast pavement.

* Corresponding author. E-mail: ameensyed20@gmail.com

Ameen SYED (ORCID ID 0000-0003-2524-7758)

Ranjan SONPAROTE (ORCID ID 0000-0001-5097-3212)

Copyright (C) 2020 The Author(s). Published by RTU Press

This is an Open Access article distributed under the terms of the Creative Commons Attribution License (http://creativecommons.org/licenses/by/4.0/), which permits unrestricted use,

distribution, and reproduction in any medium, provided the original author and source are credited. 
Good quality pavement is important for a smooth working of any city but the construction and repair of pavement in busy urban areas becomes difficult owing to the heavy traffic conditions. Construction of flexible pavement proves to be faster but such pavement requires frequent maintenance. On the contrary, frequency of maintenance required by a concrete pavement is really low, but duration of construction is relatively long. These conditions encouraged researchers around the world to consider precast concrete pavement (PCP) technology, which integrates advantages of both types of pavement ensuring fast construction and low maintenance.

The basic procedure of PCP construction is mostly similar to that of a regular concrete pavement. The base course needs to be prepared similar to that of a Cast-in-Place (CIP) concrete pavement with an addition of a levelling course just below the precast panels. Maintaining the quality of PCP is easier as such pavements are manufactured in a controlled environment and there is no scope for early age cracks and other environment-related distresses to occur (Tsuji, 1996; Tyson \& Tayabji, 2009). The finished panels should be transported to the site with the help of a wide bed trolley and placed over a perfectly prepared levelling course (Tayabji \& Wouter, 2015). PCP allows us to construct or repair a concrete pavement in a limited time, which helps reduce the accidental risks related to traffic congestion (Chen \& Chang, 2015; Syed \& Sonparote, 2017). Based upon the traffic data collected by Missouri Department of Transport (DOT), the user costs incurred due to extended lane closure are reduced by $25 \%$ in case of application of PCP, as it requires the lane to be closed only for limited non-traffic durations (Gopalaratnam, Donahue, Davis, \& Dailey, 2006). As PCP gained popularity, there have been multiple attempts to summarise and review various types of PCP technology (Priddy, Bly, \& Flintsch, 2013; Olidis, Swan, \& Saeed, 2010; Vaitkus, Gražulytė, Kleizienè, Vorobjovas, \& Šernas, 2019). In most of them, the authors focused on certain types of PCP; a comprehensive study of all popular and implemented PCP types is not available.

This paper attempts to provide a comprehensive study of the types of PCP developed worldwide for various applications such as repair of pavement, new construction, airfield application and temporary pavement application. It discusses the critical aspects of PCP, namely, panel dimensioning, load transfer mechanism, lifting provisions, stacking arrangements, transportation and base preparation method. Suitability of different types of PCP used around the world for different site situations have been considered. The latest developments and future prospects related to PCP have also been discussed. 


\section{Application of precast concrete pavement}

Over the years, PCP has proven itself useful in multiple applications. The varied applications of PCP that have been explored are:

1) intermittent repair of concrete pavement;

2) continuous construction or construction of new concrete pavement;

3) airfield repair and construction;

4) temporary concrete pavement.

\subsection{Intermittent repair application}

The earlier methods adopted for patching the damaged pavement panels or joints had a very short life span and required longer traffic disruption (Sharma, 1990). Concrete pavement can be repaired using PCP technology by removing the existing damaged panel, cleaning the cut-out area, preparing the base, placing and interlocking the PCP panel. The last two methods discussed have not gained much popularity as compared to the other methods discussed in this section.

\subsubsection{Super Slab method}

Super Slab method, patented by the Fort Miller Company, is one of the most popular methods that has been utilized for intermediate repair and continuous construction purposes (Smith, 2003). The panels are sized and reinforced according to requirement. In order to establish IPLT, holes are drilled in the existing pavement. Dowels protruding from PCP panel are inserted into these holes. These holes are later filled with a suitable grout. A grout retention disk is placed at the opening of the dowel towards the vertical face so as to stop the grout from entering the gap between adjacent panels (Olidis et al., 2010). To ensure a uniform base, a bedding grout is pressurized beneath the panels. The panels are provided with grout channels at their bottom face to ensure grout distribution. This method has been implemented at multiple locations in the USA (Table 1). It is the most widely used method for repair applications to date.

As per the falling weight deflectometer (FWD) results conducted at I-295, New Jersey, the load transfer efficiency (LTE) was found to be $65-80 \%$ after 2 years of operation (Tayabji, Dan, \& Neeraj, 2013) and in Ontario, Canada it was $84 \%$ after 6 months (Lane \& Kazmierowski, 2007). 


\begin{tabular}{|c|c|c|c|c|c|c|c|}
\hline 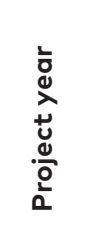 & 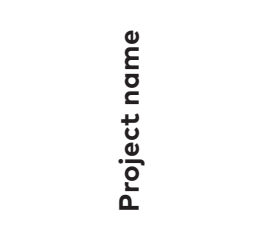 & 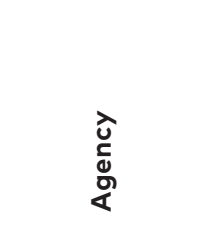 & 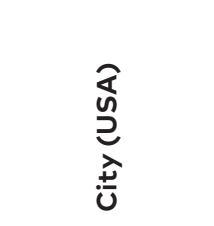 & $\begin{array}{l}3 \\
0 \\
0 \\
.5 \\
3 \\
\frac{5}{2} \\
0 \\
3\end{array}$ & 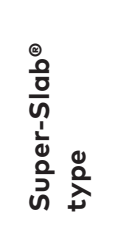 & 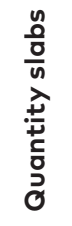 & 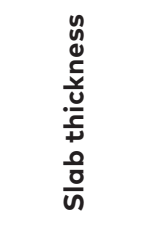 \\
\hline 2002 & $\begin{array}{l}\text { Dulles Airport } \\
\text { Taxiway }\end{array}$ & $\begin{array}{c}\text { Metro } \\
\text { Washington } \\
\text { Airports } \\
\text { Authority }\end{array}$ & Sterling & $\begin{array}{l}\text { 8-hour } \\
\text { Night }\end{array}$ & $\begin{array}{l}\text { Non- } \\
\text { Planar }\end{array}$ & 12 & 330 mm \\
\hline 2003 & $\begin{array}{l}\text { Lincoln Tunnel, } \\
\text { New Jersey }\end{array}$ & $\begin{array}{l}\text { PANYNJ } \\
\text { (Port Auth. } \\
\text { NYNJ) }\end{array}$ & Weehawken & $\begin{array}{c}\text { Over } \\
\text { weekend }\end{array}$ & Planar & 56 & $304 \mathrm{~mm}$ \\
\hline 2003 & $\begin{array}{c}\text { Korean Veterans } \\
\text { Parkway, Staten } \\
\text { Island NY }\end{array}$ & $\begin{array}{l}\text { NYSDOT (NY } \\
\text { State) }\end{array}$ & Staten Island & $\begin{array}{l}\text { 8-hour } \\
\text { Day }\end{array}$ & Planar & 90 & $203 \mathrm{~mm}$ \\
\hline 2004 & $\begin{array}{l}\text { Rt } 112 \text { Safety } \\
\text { Improvements, } \\
\text { Long Island, NY }\end{array}$ & $\begin{array}{l}\text { NYSDOT (NY } \\
\text { State) }\end{array}$ & Long Island & $\begin{array}{l}\text { 8-hour } \\
\text { Night }\end{array}$ & Planar & 29 & $229 \mathrm{~mm}$ \\
\hline 2005 & I-90 - Albany, NY & $\begin{array}{l}\text { NYSDOT (NY } \\
\text { State) }\end{array}$ & Albany & $\begin{array}{l}\text { 8-hour } \\
\text { Night }\end{array}$ & Planar & 517 & $222 \mathrm{~mm}$ \\
\hline 2004 & Toronto, Canada & $\begin{array}{l}\text { MTO (Min. } \\
\text { of Transp. } \\
\text { Ontario) }\end{array}$ & Toronto & $\begin{array}{l}\text { 8-hour } \\
\text { Night }\end{array}$ & Planar & 9 & $222 \mathrm{~mm}$ \\
\hline 2006 & $\begin{array}{l}\text { High Speed EZ } \\
\text { Pass Slabs }\end{array}$ & $\begin{array}{l}\text { NYSTA (NY } \\
\text { Thruway) }\end{array}$ & Spring Valley & $\begin{array}{l}8 \text { Hour } \\
\text { Night }\end{array}$ & Planar & 2 & $280 \mathrm{~mm}$ \\
\hline 2007 & $\begin{array}{c}\text { Southern State } \\
\text { Parkway }\end{array}$ & $\begin{array}{l}\text { NYSDOT (NY } \\
\text { State) }\end{array}$ & Long Island & $\begin{array}{l}\text { 8-hour } \\
\text { Day }\end{array}$ & Planar & 25 & $203 \mathrm{~mm}$ \\
\hline 2007 & $\begin{array}{l}\text { I - 95, New } \\
\text { Rochelle, NY }\end{array}$ & $\begin{array}{l}\text { NYSTA (NY } \\
\text { Thruway) }\end{array}$ & New Rochelle & $\begin{array}{l}\text { 5-hour } \\
\text { Night }\end{array}$ & Planar & 748 & $247 \mathrm{~mm}$ \\
\hline 2008 & $\begin{array}{c}\text { I-95, New } \\
\text { Rochelle, NY }\end{array}$ & $\begin{array}{l}\text { NYSTA (NY } \\
\text { Thruway) }\end{array}$ & New Rochelle & $\begin{array}{l}\text { 5-hour } \\
\text { Night }\end{array}$ & Planar & 45 & $247 \mathrm{~mm}$ \\
\hline 2008 & $\begin{array}{l}\text { I-295, Burlington } \\
\text { County }\end{array}$ & $\begin{array}{l}\text { NJDOT (New } \\
\text { Jersey) }\end{array}$ & Burlington & $\begin{array}{l}\text { 8-hour } \\
\text { Night }\end{array}$ & Planar & 286 & $222 \mathrm{~mm}$ \\
\hline 2009 & $\begin{array}{l}\text { Highway } 427 \\
\text { Toronto }\end{array}$ & $\begin{array}{l}\text { MTO (Min. } \\
\text { of Transp. } \\
\text { Ontario) }\end{array}$ & Toronto & $\begin{array}{l}\text { 7-hour } \\
\text { Night }\end{array}$ & Planar & 255 & $\begin{array}{c}215 \mathrm{~mm} \& \\
203 \mathrm{~mm}\end{array}$ \\
\hline
\end{tabular}




\subsubsection{Roman road system}

This system is patented by Roman Stone Construction Company (n. d.). The panels are sized and reinforced as required. IPLT is facilitated by providing top slots in the panels and cutting similar slots in the adjacent panels and laying the dowel into the slots. These slots need to be grouted before traffic opening. Polyurethane foam is used to fill any voids beneath the panel and to level the panel as per the adjacent pavement.

\subsubsection{Illinois Tollway system}

Illinois Tollway system (US) is a non-proprietary system whose demonstration project was conducted at an eastbound entrance ramp from Beverly Road onto I-90 eastbound near Elgin, Illinois in 2011 (Tayabji et al., 2013). The reinforced panels used for the project were of the size $3.73 \mathrm{~m} \times 1.83 \mathrm{~m} \times 0.254 \mathrm{~m}$. They were provided with narrow mouth top surface dowel slots for IPLT (Figure 1). These slots allow the traffic to be operational before the dowel slots are closed, hence the grouting of the slots can be performed during the next lane closure. Granular base was used to provide a level surface for laying the panels.

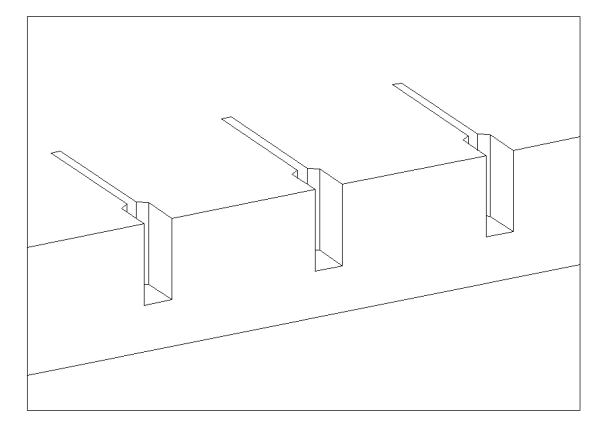

Figure 1. Narrow mouth top dowel slot

\subsubsection{UTAH DOT}

Utah Department of Transport (US) has developed a nonproprietary system and performed a demonstration project at I-215, Salt Lake County, UT. Reinforced panels used for the demonstration project were of the size $3.66 \mathrm{~m} \times 3.66 \mathrm{~m} \times 0.23 \mathrm{~m}$ and $3.66 \mathrm{~m} \times 1.83 \mathrm{~m}$ $\times 0.23 \mathrm{~m}$. To ensure IPLT, top dowel slots were used for inserting the dowel slots which were later filled with a suitable grout. Polyurethane foam was used to ensure that there are no gaps beneath the panel. 


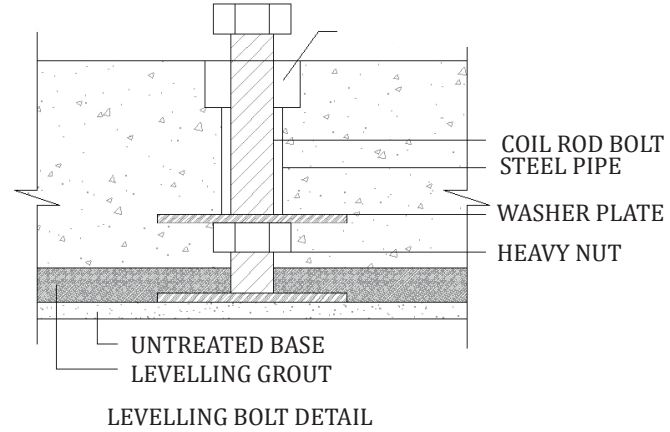

Figure 2. Threaded levelling system

Additionally, other panel was levelled using a threaded levelling system (Figure 2) and then bed grouting was performed to fill the void beneath the panel.

\subsubsection{Michigan system of full depth repair}

Michigan system of full depth repair (FDR) is a non-proprietary system for which a trial stretch was constructed at I-675 in Zilwaukee and M-25 in Port Austin. The dimensions of the panels used were $3.7 \mathrm{~m} \times$ $1.8 \mathrm{~m} \times 0.25 \mathrm{~m}$. The panels were reinforced at mid-depth with bars $10 \mathrm{~mm}$ in diameter placed at $150 \mathrm{~mm} \mathrm{c} / \mathrm{c}$. Top dowel slots were cut into the existing pavement and the repair panel with the protruding dowel bars were placed over it and the slots were then grouted to facilitate IPLT. A flowable fill was used as a levelling course (Buch, 2007). The LTE at Highway 427, Toronto, was found to be $81 \%$ soon after installation of the panels (Lane \& Kazmierowski, 2007). The LTE for repair applications needs to be matched to that of the existing pavement in order to avoid crack development in the existing pavement and was observed to be $75-85 \%$ after 7 years of construction (Tayabji et al., 2013).

\subsubsection{URETEK method}

URETEK USA Inc. has patented two methods for repair of concrete pavement. The dimensions of the panels used for Taxiway panel replacement at Washington Dulles Airport were $3.8 \mathrm{~m} \times 3.8 \mathrm{~m} \times 0.356 \mathrm{~m}$ and for north of Fort Collins on Hwy 287 near the intersection of Larimer County Road $19-3.66 \mathrm{~m} \times 4.57 \mathrm{~m} \times 0.25 \mathrm{~m}$ (DeWitt, 2006). The panels were provided with two layers of reinforcement near the top and bottom face of the panel. The methods developed by URETEK for IPLT is stitch-in-time (SIT) method, wherein steel or fibreglass plates are inserted into the saw cuts to connect the existing pavement with the 
a)

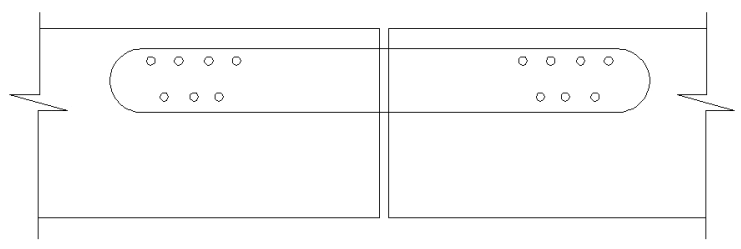

b)

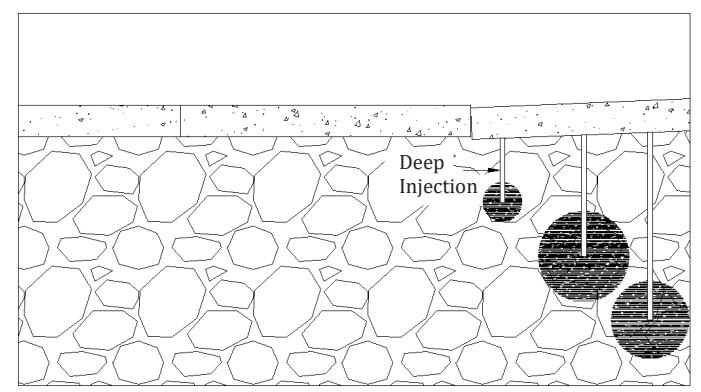

Figure 3. a) URETEK stitch-in-time method, b) URETEK deep injection method

new panel, as shown in Figure 3a. Any Base Preparation Method (BPM) can be used with it. However, the method developed by URETEK for base strengthening is deep injection method (UDI). It is the process that employs high-density polyurethane foam to lift, realign, underseal, and fill the voids beneath a concrete slab resting directly on soil, as shown in Figure 3b (Uretek, n. d.). It was implemented at I-5 Gravelly Lake to Puyallup River Project and Washington Dulles International Airport and the LTE was found to be $40 \%$ after 6 years of operation and $82-95 \%$ after panel installation, respectively (Anderson, Pierce, \& Uhlmeyer, 2007; Ashtiani \& Haro, 2014).

\subsubsection{Kwik Slab system}

The Kwik Slab system is a patented technology that has been developed in Hawaii (Yee, 2006). The panels are sized as per site requirements and are reinforced at mid-depth of the panel. The LTM used is known as Kwik joint steel couplers (Figure 4). These couplers allow two-way rebar continuity throughout the entire pavement slab. Underslab grout is used as a BPM. There is a limit to the total length of panels that can be connected; hence, expansion joints are required at short length of the pavement but have not yet been incorporated in it. It has been implemented at Campbell Industrial Park, Hawaii and Leoku Street bus stop, Hawaii (Tayabji, Buch, \& Kohler, 2008). 


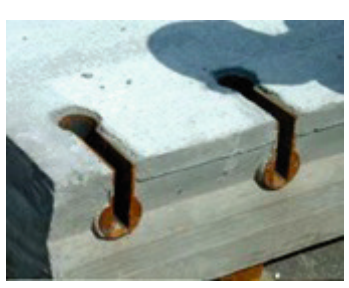

A Review of Precast Concrete Pavement Technology

Figure 4. Kwik joint steel couplers (Tayabji et al., 2008)

\subsubsection{Repair of M59, USA}

In the 1970s, a pavement selection committee, established by the US, proposed to use precast panels for repair of four distressed panels at M59 (Highway) Livingston County, US. The dimensions of the repair panels used were $3.35 \mathrm{~m} \times 1.83 \mathrm{~m} \times 0.1 \mathrm{~m}$. The panel was reinforced using No. 3 bars at $0.15 \mathrm{~m} \mathrm{c} / \mathrm{c}$ as top reinforcement and No. 3 bars at $0.3 \mathrm{~m} \mathrm{c} / \mathrm{c}$ as bottom reinforcement. In one repair panel, steel dowels and steel plates were used to facilitate load transfer between adjacent panels (Figure 5a) while in another panel the load transfer mechanism (LTM) was adopted (Figure 5b). The base for laying the panels was prepared using a cement-sand mortar slurry (Simonsen, 1971). There are no reports quantifying the performance of this repair method and no other implementation was documented.

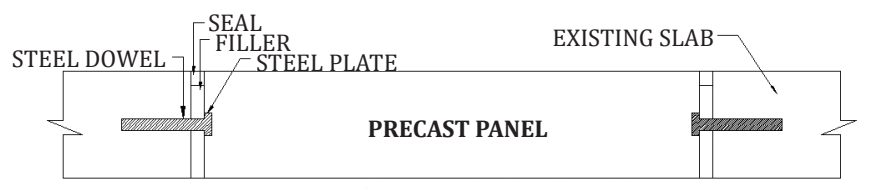

a) WITH LOAD TRANSFER

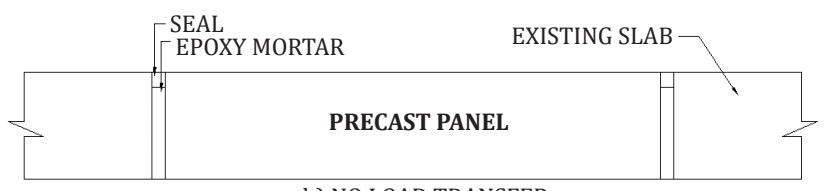

b) NO LOAD TRANSFER

Figure 5. Types of joints used at M59 Livingston County

\subsubsection{IH-30, Texas}

In the 1980s, continuously reinforced concrete pavement (CRCP) was repaired using precast polymer concrete panels at IH-30, Nr Mt. Pleasant, Texas, USA. The distressed panels were removed and clear pits were 
prepared using fast setting flowable grout. One pit sized $3.66 \mathrm{~m} \times 3.66 \mathrm{~m}$ $\times 0.195 \mathrm{~m}$ was replaced by a panel of size $3.25 \mathrm{~m} \times 3.25 \mathrm{~m} \times 0.195 \mathrm{~m}$ and the other pit sized $1.83 \mathrm{~m} \times 1.83 \mathrm{~m} \times 0.195 \mathrm{~m}$ was replaced by a panel of $1.42 \mathrm{~m} \times 1.42 \mathrm{~m} \times 0.195 \mathrm{~m}$. The reinforcement exposed upon the removal of the damaged pavement was welded with the reinforcement of the repair panel so as to facilitate inter panel load transfer (IPLT). The panel base was laid with fast setting grout so as to provide a uniform support, and levelling beams were used to ensure that the panel acquires the required level (Meyer, McCullough, \& Fowler, 1981). There are no reports regarding the performance of this pavement, hence it can only be used in a deliberate and controlled manner.

\subsection{Continuous construction (new construction)}

Attempts to make use of precast pavement technology for construction of new pavement have been made since the 1960s (Rollings \& Chou, 1981). The benefit of using PCP is that it allows the construction of the pavement without hindrance to traffic. PCP can be used in cases where the road is to be made operational at the earliest. The last method explained in this section did not gain high popularity.

\subsubsection{Super Slab method}

Fort Miller's Super Slab method can also be used for continuous application purposes. The dimensions of the reinforced panels required can be decided as per site requirements. The IPLT is facilitated by providing the panels with bottom dowel slots at one edge and protruding dowels at the other edge of the panel (Figure 6). Traffic cannot be allowed before dowel slot grouting as the LTE before grouting is found to be $10 \%$ and after grouting is found to be $100 \%$ (Kohler, Smith, Harvey, \& Pyle, 2007). Grouted BPM is used to ensure uniform support to the panels. One of the most unique features of this method is that it has wrapped panels in order to incorporate the curves (Daigle, 1974).

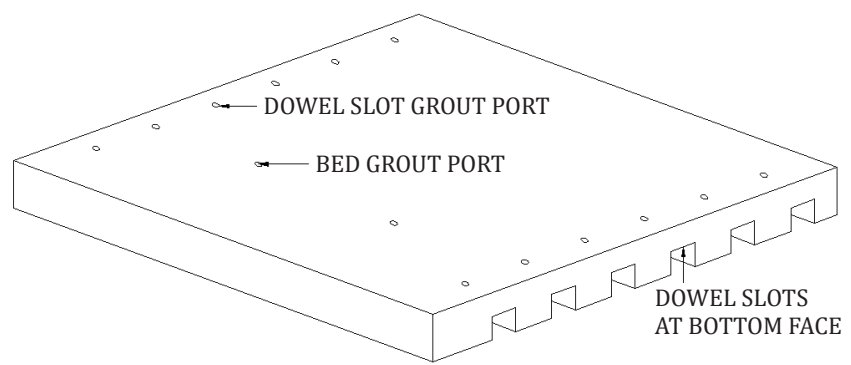

Figure 6. Fort Miller's Super Slab method 


\begin{tabular}{|c|c|c|c|c|c|c|c|}
\hline $\begin{array}{l}\stackrel{u}{0} \\
\stackrel{d}{0} \stackrel{0}{0} \\
\dot{0} 0 \\
0\end{array}$ & $\begin{array}{l}\stackrel{\sharp}{U} \\
\stackrel{0}{0} \\
\stackrel{0}{0}\end{array}$ & 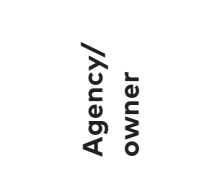 & 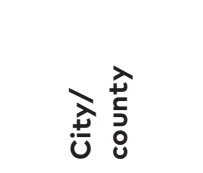 & $\begin{array}{r}3 \\
\times \frac{3}{0} \\
3 \\
3 \\
3\end{array}$ & 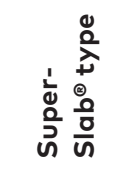 & 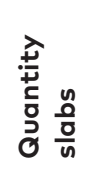 & 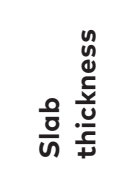 \\
\hline 2002 & $\begin{array}{l}\text { Tappanzee } \\
\text { Bridge Toll Plaza }\end{array}$ & $\begin{array}{l}\text { NYSTA (NY } \\
\text { Thruway) }\end{array}$ & South Nyack & $\begin{array}{l}\text { Off Peak } \\
\text { Hours }\end{array}$ & Planar & 1088 & $255 \mathrm{~mm}$ \\
\hline 2001 & $\begin{array}{l}\text { Sagamore Bridge } \\
\text { Rehab }\end{array}$ & $\begin{array}{l}\text { Sagamore } \\
\text { Resort }\end{array}$ & $\begin{array}{l}\text { Bolton } \\
\text { Landing }\end{array}$ & $\begin{array}{l}\text { 8-hour } \\
\text { Day }\end{array}$ & Planar & 4 & $304 \mathrm{~mm}$ \\
\hline 2003 & $\begin{array}{l}\text { 9A Ramp } \\
\text { Tarrytown }\end{array}$ & $\begin{array}{l}\text { NYSTA (NY } \\
\text { Thruway) }\end{array}$ & Tarrytown & $\begin{array}{l}\text { Day \& } \\
\text { night }\end{array}$ & $\begin{array}{l}\text { Non- } \\
\text { planar }\end{array}$ & 76 & $188 \mathrm{~mm}$ \\
\hline 2003 & $\begin{array}{l}\text { Belt Parkway } \\
\text { Ramps, Jamaica } \\
\text { NY }\end{array}$ & $\begin{array}{l}\text { NYSDOT (NY } \\
\text { State) }\end{array}$ & Jamaica & $\begin{array}{l}\text { One } \\
\text { month }\end{array}$ & $\begin{array}{l}\text { Non- } \\
\text { planar }\end{array}$ & 99 & $255 \mathrm{~mm}$ \\
\hline 2005 & $\begin{array}{l}\text { Crosswalks, Port } \\
\text { Jefferson, NY }\end{array}$ & $\begin{array}{l}\text { NYSDOT (NY } \\
\text { State) }\end{array}$ & $\begin{array}{l}\text { Port } \\
\text { Jefferson }\end{array}$ & $\begin{array}{l}\text { 8-hour } \\
\text { Night }\end{array}$ & $\begin{array}{l}\text { Non- } \\
\text { planar }\end{array}$ & 10 & $229 \mathrm{~mm}$ \\
\hline 2005 & $\begin{array}{l}\text { Heavy Vehicle } \\
\text { Simulator (HVS) } \\
\text { Test I-15 }\end{array}$ & $\begin{array}{l}\text { Caltrans } \\
\text { (Califorina) }\end{array}$ & Fontana & $\begin{array}{l}\text { Off } \\
\text { highway }\end{array}$ & Planar & 10 & $222 \mathrm{~mm}$ \\
\hline 2004 & Minneapolis, MN & $\begin{array}{l}\text { MnDOT } \\
\text { (Minnesota) }\end{array}$ & Minneapolis & $\begin{array}{l}\text { Full } \\
\text { closure }\end{array}$ & Planar & 18 & $235 \mathrm{~mm}$ \\
\hline 2005 & Marine Parkway & $\begin{array}{l}\text { Metropolitan } \\
\text { Transit Auth. } \\
\text { NY }\end{array}$ & Brooklyn & $\begin{array}{l}\text { 3-day } \\
\text { closure }\end{array}$ & $\begin{array}{l}\text { Non- } \\
\text { planar }\end{array}$ & 54 & $222 \mathrm{~mm}$ \\
\hline 2006 & $\begin{array}{l}\text { Fenimore Rd. } \\
\text { Comm Drives }\end{array}$ & $\begin{array}{l}\text { Village of } \\
\text { Mamaroneck }\end{array}$ & Mamaronek & $\begin{array}{l}\text { Off } \\
\text { highway }\end{array}$ & Planar & 42 & $222 \mathrm{~mm}$ \\
\hline 2006 & $\begin{array}{l}\text { Schuylerville, NY } \\
\text { Trial }\end{array}$ & $\begin{array}{l}\text { NYSDOT (NY } \\
\text { State) }\end{array}$ & Schulyerville & $\begin{array}{l}\text { Off } \\
\text { highway }\end{array}$ & $\begin{array}{l}\text { Both P } \\
\& N P\end{array}$ & 6 & $222 \mathrm{~mm}$ \\
\hline 2006 & $\begin{array}{l}\text { Fordham Rd. } \\
\text { Bronx, NY }\end{array}$ & $\begin{array}{l}\text { NYSDOT (NY } \\
\text { State) }\end{array}$ & Bronx & $\begin{array}{l}\text { 8-hour } \\
\text { Night }\end{array}$ & $\begin{array}{l}\text { Both } P \\
\& N P\end{array}$ & 19 & $203 \mathrm{~mm}$ \\
\hline 2006 & $\begin{array}{l}\text { RT \& Crosstown } \\
\text { Schenectady, NY }\end{array}$ & $\begin{array}{l}\text { NYSDOT (NY } \\
\text { State) }\end{array}$ & Schenectady & $\begin{array}{l}\text { 10-hour } \\
\text { Night }\end{array}$ & $\begin{array}{l}\text { Both P } \\
\& N P\end{array}$ & 181 & $222 \mathrm{~mm}$ \\
\hline 2007 & Chicago, IL Trial & $\begin{array}{l}\text { ISTHA (Illinois } \\
\text { Tollway) }\end{array}$ & Chicago & $\begin{array}{l}\text { Off } \\
\text { highway }\end{array}$ & Planar & 4 & $304 \mathrm{~mm}$ \\
\hline 2007 & I-294 Chicago & $\begin{array}{l}\text { ISTHA (Illinois } \\
\text { Tollway) }\end{array}$ & Chicago & $\begin{array}{l}\text { 8-hour } \\
\text { Night }\end{array}$ & $\begin{array}{l}\text { Both P } \\
\& N P\end{array}$ & 18 & $304 \mathrm{~mm}$ \\
\hline 2008 & I-88 Chicago & $\begin{array}{l}\text { ISTHA (Illinois } \\
\text { Tollway) }\end{array}$ & Chicago & Weekend & Planar & 22 & $330 \mathrm{~mm}$ \\
\hline
\end{tabular}




\begin{tabular}{|c|c|c|c|c|c|c|c|}
\hline 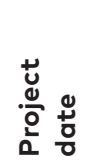 & 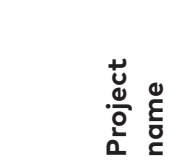 & 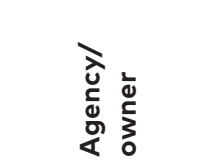 & 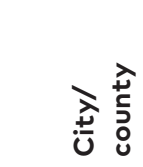 & $\begin{array}{l}3 \\
\times \frac{3}{2} \\
\frac{0}{2} \\
3 \\
3\end{array}$ & 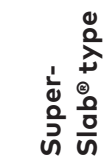 & 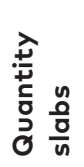 & 음 \\
\hline 2008 & $\begin{array}{l}\text { Highway } 427 \\
\text { Toronto }\end{array}$ & $\begin{array}{l}\text { MTO (Min. } \\
\text { of Transp } \\
\text { Ontario) }\end{array}$ & Toronto & $\begin{array}{l}\text { 7-hour } \\
\text { Night }\end{array}$ & Planar & 115 & $215 \mathrm{~mm}$ \\
\hline 2009 & $\begin{array}{l}\text { Highway } 427 \\
\text { Toronto }\end{array}$ & $\begin{array}{l}\text { MTO (Min. } \\
\text { of Transp } \\
\text { Ontario) }\end{array}$ & Toronto & $\begin{array}{l}\text { 7-hour } \\
\text { Night }\end{array}$ & Planar & 255 & $\begin{array}{c}215 \mathrm{~mm} \\
\& 203 \\
\mathrm{~mm}\end{array}$ \\
\hline 2007 & I-88 Chicago & $\begin{array}{l}\text { ISTHA (Illinois } \\
\text { Tollway) }\end{array}$ & Chicago & $\begin{array}{l}\text { 8-hour } \\
\text { Night }\end{array}$ & Planar & 3 & $304 \mathrm{~mm}$ \\
\hline
\end{tabular}

It was first implemented at multiple locations given in Table 2 . Accelerated load testing has been performed by California DOT and the results prove the efficiency of this system (Kohler et al., 2007). The LTE obtained at Tappan Zee Toll Plaza, New York, TH 62, Minnesota, I-66 Ramp, Virginia, I-295, New Jersey and I-280, New Jersey is $85 \%$ after 9 years of operation, $90 \%$ after 5 years of operation, $90 \%$ after 1.5 years of operation, $75 \%$ after 2 years of operation and $80 \%$ after 1 year of operation, respectively (Tayabji \& Ye, 2010).

\subsubsection{Prestressed precast concrete pavement (PPCP) method}

Prestressed precast concrete pavement (PPCP) is a generic method developed by the University of Texas; it has been utilized exclusively for continuous construction (Cable, McCullough, \& Burns, 1985). Posttensioned PCP panels are extra thin panels, which are pre-tensioned perpendicular to the traffic direction and multiple PCP panels are post-tensioned together along the traffic direction. PPCP panels having dimensions $3.65 \mathrm{~m} \times 2.44 \mathrm{~m}$ were tested and found to provide excellent service life (Alwehaidah \& Russell, 2018). PPCP panel dimensions used in Indonesia are $2.5 \mathrm{~m} \times 8.2 \mathrm{~m}$ (Nantung, Firmansjah, Suwarto, \& Hidayat, 2010), in California - $11.28 \mathrm{~m} \times 2.44 \mathrm{~m}$ (Merritt, McCullough, \& Burns, 2005), in Missouri - $3.0 \mathrm{~m} \times 11.58 \mathrm{~m}$ (Merritt, Rogers, \& Rasmussen, 2008), in Iowa Bridge approach slab dimensions are $6.10 \mathrm{~m} \times 4.3 \mathrm{~m}$ (Merritt, Miron, Rogers, \& Rasmussen, 2007), in Texas $-11.58 \mathrm{~m} \times$ $3.0 \mathrm{~m}$ (Merritt, Mccullough, \& Burns, 2002), in Delaware $-7.3 \mathrm{~m} \times 3.0 \mathrm{~m}$ (Tyson \& Tayabji, 2009), in Mississippi $-7.3 \mathrm{~m} \times 2.36 \mathrm{~m}$ (Tayabji, 2001) and in Virginia $-8.23 \mathrm{~m} \times 3.0 \mathrm{~m}$ (Rao, Sadasivam, Littleton, Ullman, \& Mallela, 2012). In general, the size of PPCP panels may be much larger than other types of PCP and it may vary drastically. The panels do not 
have any dowels as the post-tensioning behaves like an LTM, thereby easing the construction process. Either an asphalt base, lean concrete base, permeable asphalt treatment, or graded BPM may be used for base levelling. A polythene sheet is necessarily pulled over the prepared base in order to reduce friction between the base and the panels (Chen \& Chang, 2015). PPCP is of three types (Figure 7) (Tayabji, 2014):

1) PPCP having base panels, central prestressed panels and expansion joint panels;

2) PPCP having base panels and expansion joint panels with surface prestressing;

3) PPCP having base panels and expansion joint gap panels with vertical face prestressing.

The design steps for PPCP have been suggested by Fugro consultants (2012). Based upon their design, PPCP has been implemented at Route 710, 405 and 5 in California (Fugro Consultants, 2012). It has also been implemented in USA, Japan, Indonesia, and Philippines.

PPCP in itself is a generic technology, but there are few variants of this technology that are patented. In one of these patents, prestressing is performed inclined to the traffic direction, in an attempt to create prestress effect in both lateral and longitudinal direction using only

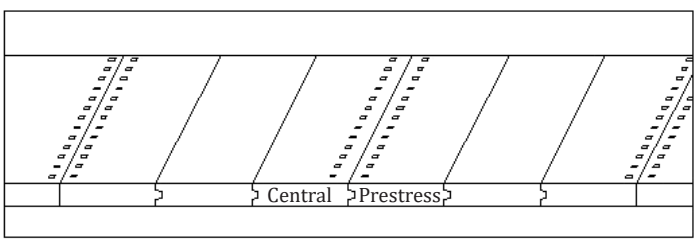

a) Central Prestress

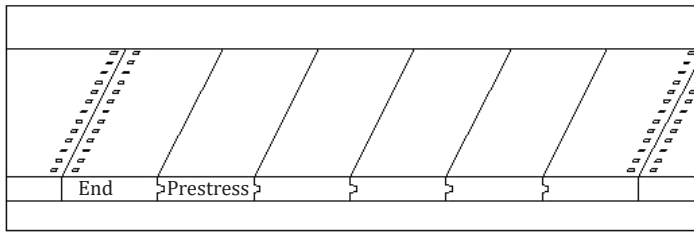

b) End Prestress

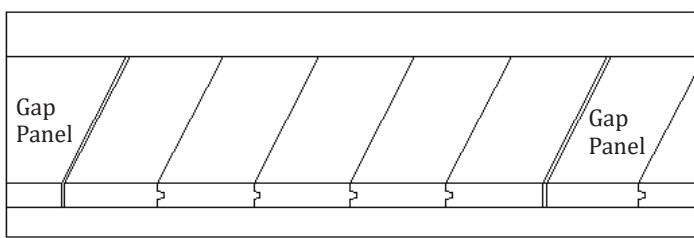

c) Gap Prestress

Figure 7. PPCP types 
single set of strands (Barnett, 1980). In 1946, at Orly Airport, France, the PPCP slabs were triangular shaped and were prestressed in the transverse direction (Klunker, 1981). Both of these projects did not prove to be much effective and hence were not considered for further development.

\subsubsection{Keyed hexagonal panel method}

Keyed hexagonal slab panels have been utilized in France by researchers at the Pont et Chaussées laboratories. Hexagonal reinforced panels fitting in a circle of $1.54 \mathrm{~m}$ in diameter with the thickness of $0.2 \mathrm{~m}$ in general and $0.21 \mathrm{~m}$ at the edges were used in Austin, and those with the thickness of $0.19 \mathrm{~m}$ were used in Nantes. IPLT was not provided in Austin and haunches interlocking was provided in Nantes (Figure 8). Panels were laid over a granular base spread over a unique Structural Excavatable Cement Treated Material (SECTM). SECTM provides a strong base to the precast panels and at the same time is easy to remove (Larrard, Sedran, \& Balay, 2013).

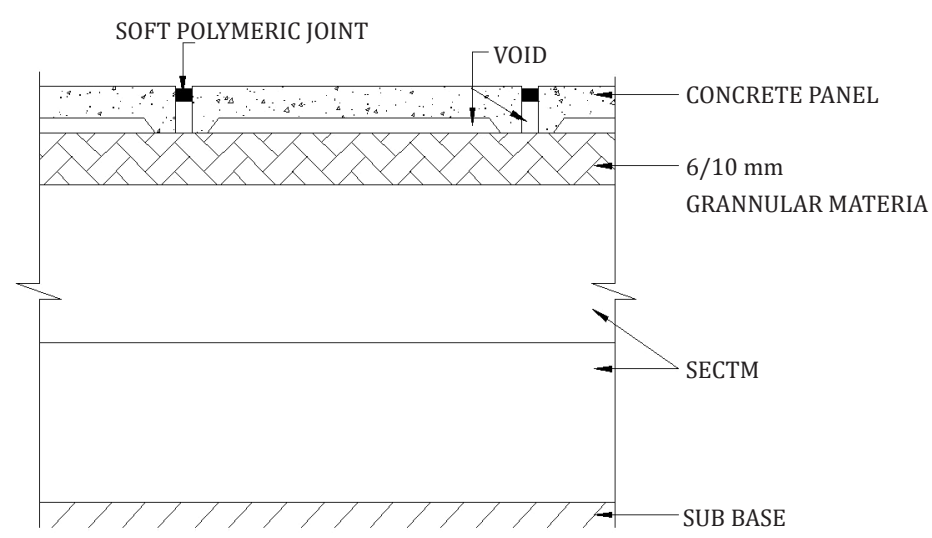

Figure 8. Joint in Nantes, France

\subsubsection{South Dakota tongue and fork method}

In 1968, a precast concrete pavement with an asphalt concrete overlay was implemented in South Dakota, US (Hargett, 1986). The dimensions of the panels used were $7.3 \mathrm{~m} \times 1.83 \mathrm{~m} \times 0.125 \mathrm{~m}$. These panels were prestressed in order to strengthen them further and to reduce panel thickness. The panels are interconnected using a tongue and fork connection, as shown in Figure 9. The base of the panel 


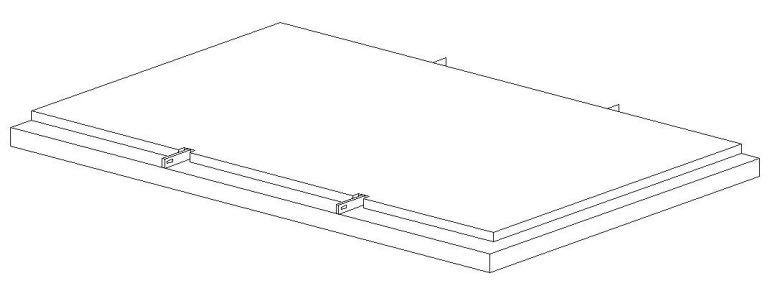

A Review of Precast Concrete Pavement Technology

Figure 9. Tongue and fork connection

consisted of a 1.5 inch of sand bedding over an 8inch thick granular base (Gaudelli \& Shepler, 1987). This technique turned out to be unsuccessful, but led to the development of improved methods.

Apart from the previously mentioned methods that deal with standard vehicular loads, a number of other methods have also been developed for quick construction of pavements exclusively for lightweight vehicles. There are no reports available regarding any field trials of these projects. These technologies provide a simple method of PCP construction, as shown in Figure 10 (Gaudelli \& Shepler, 1987; Green, 1983; Lee, 2004; Reese \& Keech, 1992).

\subsection{Airfield application}

Airfield repair is one of the oldest and most important applications of PCP, as the closure of an airfield results in heavy traffic disruption. Repair of military airfields generally occurs at the time of war and hence
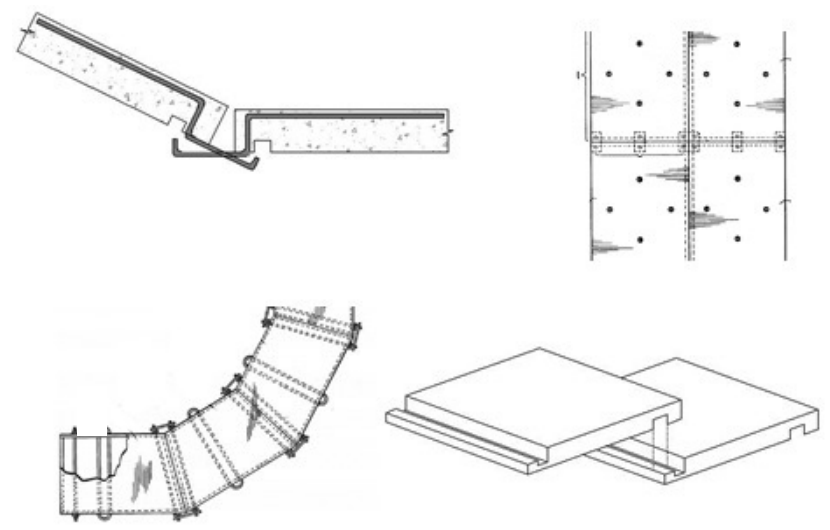

Figure 10. Interlocking arrangement for light loads 
needs to be done as fast as possible and with a minimum requirement of new materials. PCP has been applied in a number of places for airfield repair. Few simple methods for quick airfield repairs were developed in the 1980s. Multiple attempts have been made to understand the application of different types of PCP for airport application (Bly, Priddy, Jackson, \& Mason, 2013; Brabston, 1984; Qu et al., 2017). Some of the popular methods are mentioned below.

\subsubsection{La Guardia International Airport method}

La Guardia International Airport method is a generic system developed on demand by the Port Authority of New York and New Jersey (PANY/NJ). They investigated the use of precast concrete pavement to rehabilitate Taxiway A and Taxiway D-D. In order to develop the technology, PANY/NJ constructed two $60.96 \mathrm{~m}$ test sections at a noncritical taxiway in 2002 (Chen, Murrell, \& Larrazabal, 2004). Trial stretch one had reinforced panels having size $7.62 \mathrm{~m} \times 3.81 \mathrm{~m} \times 0.406 \mathrm{~m}$ and trial stretch two had prestressed panels $7.62 \mathrm{~m} \times 3.81 \mathrm{~m} \times 0.304 \mathrm{~m}$ in size. Dowel slots were cut at the panel tops to incorporate the dowels and facilitate IPLT upon grouting. To ensure uniform support to the panels, grouted BPM was used along with levelling arrangement similar to that used by UTHAD DOT.

\subsubsection{Japanese prestressed PCP method}

A project taken up in Japan used prestressed PCP. Seven pavements were examined; panel sizes were in the range $4-10 \mathrm{~m} \times 1.3-2 \mathrm{~m} \times$ 0.17-0.2 $\mathrm{m}$. The panels were prestressed longitudinally and reinforced laterally. Two types of LTM were used to interconnect the panels, namely, Horn Device LTM and Sliding LTM (Hara, Takuya, Matsuno,

a)

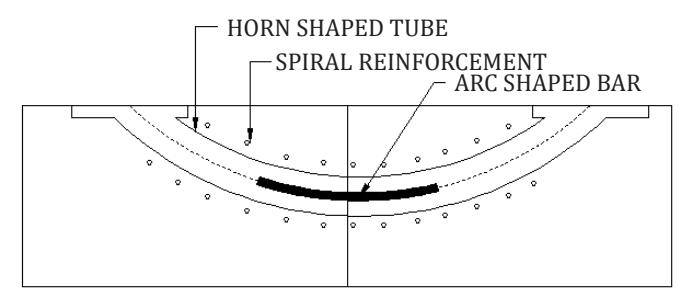

b)

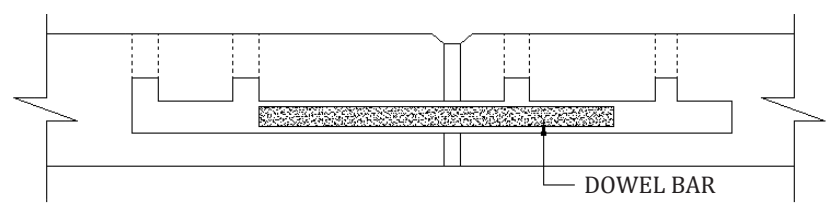

Figure 11. a) Horn device, b) Sliding dowel bar joint 
\& Nishizawa, 1997). Horn Device is a system where curved slots are Concrete Pavement provided into the PCP panel and later a horn shaped bar is inserted into the slot (Figure 11a). The dowel slot is then filled with a suitable grout. In Sliding LTM, the dowel bar is inserted into the long slot provided in one panel. After the placement of the adjacent panel, the dowel is slid from the longer slot into the shorted dowel slot in the adjacent panel (Figure 11b). The slot is then grouted. The base for these panels maybe prepared as per site requirements. PCP has also been used in Japan for tunnel applications (Tayabji, 2010)

\subsubsection{Soviets PCP method}

In the 1960s and 1970s, the Soviets used precast concrete pavement technology for airfield applications. Several trials performed with varying panel sizes and thicknesses determined that $2 \mathrm{~m} \times 6 \mathrm{~m} \times$ $0.14 \mathrm{~m}$ slab dimensions provide the best configuration. The panels were reinforced with a double layered mesh of $12 \mathrm{~mm}$ bars (Sapozhnikov \& Rollings, 2007). A unique feature of this technology is the lifting hoops provided at the edges of the panels, as shown in Figure 12. Once the panels were set in the required position, these lifting hoops were welded together so as to provide load transfer among adjacent panels. The slot developed was later filled with a suitable grout. A granular base

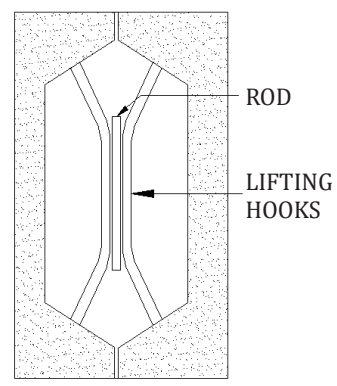

Figure 12. Welded lifting hoops

using sand was prepared for laying the panels. It was implemented at Afghanistan Airstrip that was developed by the former USSR.

\subsubsection{Airforce method}

Airforce method has recently been developed in the US for the repair of airfield pavement. Reinforced panels used in the demonstration project were of size $3.0 \mathrm{~m} \times 3.0 \mathrm{~m} \times 0.28 \mathrm{~m}$. In order to facilitate IPLT, top 
slots were worked into the panels which were later provided with dowel bars and filled with a suitable grout. Among three trial panels placed, polyurethane foam BPM was used for two panels and flowable fill BPM was used for one panel. Currently, US Airforce Research Laboratory is working on improving the panel design (Priddy et al., 2013).

\subsubsection{Mat method}

A mat PCP was designed to carry missile carriers by US Army Corps of Engineering (Priddy, 2015). Prestressed panels of the size $5.5 \mathrm{~m} \times$ $0.3 \mathrm{~m} \times 0.136 \mathrm{~m}$ (at ribs) and $0.068 \mathrm{~m}$ (between the ribs) were used for this purpose (Figure 13). The IPLT was facilitated by posttensioning and

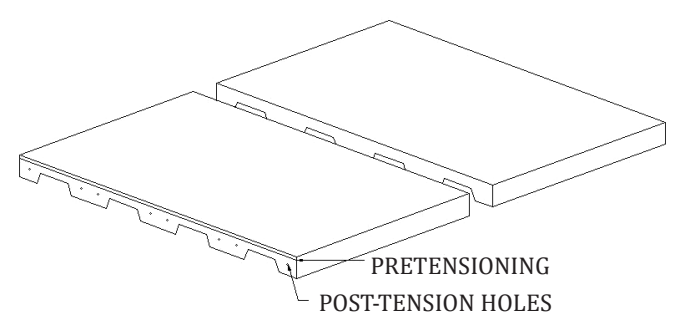

Figure 13. Mat precast pavement

the bed preparation was prepared by granular BPM. The slab was cast using lightweight aggregates and designed such that 8-10 men can lift and place them if needed (Bull, 1991).

\subsection{Temporary application}

In a test project sponsored by Florida DOT, temporary unreinforced precast panels were used to fill up the pits created upon removal of distressed pavement before the cast-in-situ concrete could be

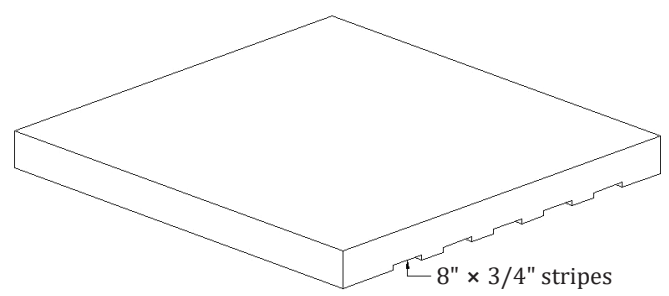

Figure 14. Stripes at the base of the panel 
poured. This resulted in a $20 \%$ cost saving for the contractor. The Concrete Pavement panels exhibited multiple cracks at the end of their use, mainly due to the lack of reinforcement. The next set of panels used for the field test were reinforced, their size was $3.58 \mathrm{~m} \times 1.75 \mathrm{~m} \times 0.23 \mathrm{~m}$ and $3.62 \mathrm{~m} \times 1.14 \mathrm{~m} \times 0.23 \mathrm{~m}$. No LTM was adopted for these panels as they were implied only for temporary application and hence were not interconnected. In order to place these panels, a uniform base was prepared using granular material. Additionally, the panels had $200 \mathrm{~mm} \times$ $19 \mathrm{~mm}$ stripes at the base perpendicular to the traffic direction (Figure 14) so as to provide better friction and interlocking of the precast panel with the base (Tawfiq \& Armaghani, 2016).

\section{Discussion regarding PCP}

In order to successfully complete a PCP project, it is necessary to understand the critical aspects of PCP, as well as the suitability of different types of PCP for the project site conditions. Based upon the detailed study of PCP it can be said that there are certain aspects of PCP that are crucial for the successful implementation of a PCP project. These aspects are the key aspects that differentiate one type of PCP from the other. Before starting any PCP project, it is necessary that the right decisions regarding these aspects are made for gaining the maximum benefit of the technology. These aspects are:

1) panel dimensioning;

2) load transfer mechanism (LTM);

3) lifting arrangement and stacking;

4) transportation;

5) base preparation method (BPM);

6) other aspects.

\subsection{Panel dimensioning}

The dimensions of a panel are affected greatly by the type of PCP used. The types of PCP panels for the purpose of panel dimensioning are:

\subsubsection{Reinforced PCP}

Reinforced PCP are not extra thin due to the lack of prestressing and hence there is no significant material saving. The panels are generally provided with a single or two layers of reinforcement. Research sponsored by Florida DOT performed Accelerated Pavement Test (APT) upon PCP panels prepared for temporary pavement application having size $1.83 \mathrm{~m} \times 3.66 \mathrm{~m} \times 0.10 \mathrm{~m}$; the panels behaved exceptionally well 
(Tawfiq \& Armaghani, 2016). In Philippines, PCP panels were used for repair applications and the size of the panels used was $4.0 \mathrm{~m} \times$ $3.5 \mathrm{~m} \times 0.33 \mathrm{~m}$ (Enriquez, Pabuna, \& Sawali, 2013). In Minnesota and Colorado, $3.66 \mathrm{~m} \times 3.66 \mathrm{~m} \times 0.23 \mathrm{~m}$ sized panels were used (Burnham, 2007; DeWitt, 2006). A study conducted to understand the effect of concrete mix and panel dimensions on panel thickness concluded that the optimum size of reinforced PCP panels is $3.50 \mathrm{~m} \times 4.40 \mathrm{~m}$ (Vaitkus, Kleizienè, Vorobjovas, \& Čygas, 2019).

\subsubsection{Pre-tensioned PCP}

Pre-tensioned PCP panels are pre-tensioned to help reduce the thickness of the panels and are additionally provided with a nominal reinforcement. The panels are also provided with a suitable dowelled LTM to facilitate load transfer between the panels, unlike post-tensioned PCP where there is no dowelled LTM. The size of the panels is restricted to $3.5 \mathrm{~m} \times 4.5 \mathrm{~m}$.

\subsubsection{Post-tension precast panels (PPCP)}

Post-tensioned PCP panels are the panels, which are pre-tensioned perpendicular to the traffic direction, and multiple PCP panels are post-tensioned together along the traffic direction. The post-tensioning behaves like an LTM thereby easing the construction process; it provides an excellent riding surface. PPCP panels having dimensions $3.65 \mathrm{~m} \times 2.44 \mathrm{~m}$ were tested and found to provide excellent service life (Alwehaidah \& Russell, 2018). PPCP panel sizes used in Indonesia are $2.5 \mathrm{~m} \times 8.2 \mathrm{~m}$ (Nantung et al., 2010; Tayabji et al., 2013), in California $11.28 \mathrm{~m} \times 2.44 \mathrm{~m}$ (Chen \& Chang, 2015), in Missouri $-3.0 \mathrm{~m} \times 11.58 \mathrm{~m}$ (Gopalaratnam et al., 2006), at Iowa Bridge, approach slab is $6.10 \mathrm{~m}$ $\times 4.3 \mathrm{~m}$ (Merritt et al., 2007), in Texas $-11.58 \mathrm{~m} \times 3.0 \mathrm{~m}$ (Merritt, McCullough, \& Burns, 2001), in Delaware $-7.3 \mathrm{~m} \times 3.0 \mathrm{~m}$ (Tyson \& Tayabji, 2009) and in Mississippi $-7.3 \mathrm{~m} \times 2.36 \mathrm{~m}$ (Tayabji, 2001). In general, the size of PPCP panels may be much larger than the previous two types and may vary drastically.

Increase in the size of the PCP panels also causes increase in the required thickness (except if prestressed); consequently, the weight of the panel increases making it difficult to handle. If there are no budget restrains for the project, the application of PPCP allows the most optimized usage of material and thin large sized panels that provide an excellent riding quality. Alternatively, if there are budget constrains but prestressing facilities are available, then it is better to use prestressed PCP as it provides thinner sections that ensures material saving as well as removes the need of a high capacity crane. Irrespective of the type of 


\begin{tabular}{lc}
\hline \multicolumn{1}{c}{ Panel Feature } & Tolerance \\
\hline Length & $6 \mathrm{~mm}$ \\
Width & $3 \mathrm{~mm}$ \\
Thickness & $3 \mathrm{~mm}$ \\
Edge alignment straightness measured & $3 \mathrm{~mm}$ \\
from horizontal plane & $3 \mathrm{~mm}$ \\
Skew at ends & $3 \mathrm{~mm}$ \\
Difference of diagonal corner to corner & \\
measurement & $6 \mathrm{~mm}$ \\
Block out dimensions (if applicable) & $3 \mathrm{~mm}$ \\
Location of lifting inserts & $6 \mathrm{~mm}$ \\
Pre-tensioning strand position & $\pm 1 / 2$ in \\
Vertical location of reinforcement & $6 \mathrm{~mm}$ over $3 \mathrm{~m}$ in any direction \\
Local smoothness of any surface & \\
\hline
\end{tabular}

PCP selected, it is important to cast the panel of a proper quality. This can be achieved by ensuring that the tolerances mentioned in Table 3 are followed.

\subsection{Load transfer mechanism (LTM)}

Load transfer mechanism (LTM) is responsible for the transfer of load between adjacent panels. An efficient load transfer system will reduce any impact that may develop when a wheel crosses from one panel to another. There are multiple LTM developed throughout the world that are mentioned in Table 4.

There are two generalized methods of calculating load transfer efficiency (LTE) using a falling weight deflectometer (FWD). The method of calculating LTE are system rutting model (Eq. (1)) and layer rutting model (Eq. (2)) (Ashtiani \& Haro, 2014). LTE of over 70\% should be maintained for the long-term performance of the pavement (Smith \& Snyder, 2016). In CIP pavement construction, LTM, aggregate interlocking and bed load transfer contribute to the LTE of the pavement. The lack of aggregate interlocking in PCP exaggerates the importance of LTM.

$$
L T E_{d}=\frac{d_{u}}{d_{l}}
$$




\begin{tabular}{|c|c|c|}
\hline & Type of LTM & Reference \\
\hline \multirow{13}{*}{$\begin{array}{l}\text { Implemented } \\
\text { load transfer } \\
\text { mechanisms }\end{array}$} & Threaded Sliding & Tsuji, 1996 \\
\hline & Bottom Dowel Slot & Smith, 2003 \\
\hline & Kwik Joint Steel Coupler & Yee, 2006 \\
\hline & Horn Device & Sato, Fukute, \& Inukai, 1981 \\
\hline & Top Dowel Slot & \\
\hline & URETEK Stitch in Time & Anderson et al., 2007 \\
\hline & Prestressed & \\
\hline & Welded & Sapozhnikov \& Rollings, 2007 \\
\hline & Sliding Slot & Enriquez et al., 2013 \\
\hline & Joint Prestressed & Kumakura, Kondo, Kai, Abe, \& Sato, 1994 \\
\hline & Narrow Mouth & Tayabji et al., 2013 \\
\hline & Lateral Dowel & Syed \& Sonaprote, 2019 \\
\hline & Grout Shear Key & Rollings \& Chou, 1981 \\
\hline \multirow{6}{*}{$\begin{array}{l}\text { Not } \\
\text { implemented } \\
\text { load transfer } \\
\text { mechanisms }\end{array}$} & Hook and Tie & Yeoman, 1957 \\
\hline & Bottom Hook Interlocking & Daigle, 1974 \\
\hline & Interlocking Cement Slab (T \& G LTM) & Daigle, 1974; Gaudelli \& Shepler, 1987 \\
\hline & Mechanized Sliding Slot & Ulislam, 2014 \\
\hline & Deformable Steel Tube & Rollings \& Chou, 1981 \\
\hline & Male-Female & Syed \& Sonparote, 2017 \\
\hline
\end{tabular}

$$
L T E_{d}^{*}=\frac{2 d_{u}}{d_{l}+d_{u}},
$$

where $d_{u}$ - deflection in unloaded panel; $d_{l}$ - deflection in loaded panel.

The selection of an appropriate LTM influences the quality of the pavement as well as the economy of the project. It is important to select a method that is tried and tested and avoid the methods whose performance and practicality can only be judged upon by performing additional experiments. The construction of PPCP is very efficient but it is costly and requires very accurate panels. If there is a constraint on the budget, then it is better to avoid PPCP as well as other patented methods. The types of LTMs that can be used within these restrictions are top dowel slot, narrow mouth, sliding slot and lateral dowel LTM. Sliding slot LTM has been used at multiple locations and provides an excellent surface quality, but it requires high precision moulds and 
consecutively high precision panels. If there is no yard available with Concrete Pavement the capacity to produce high precision panels with all the LTM details, then the best available solution is top slot LTM and narrow mouth LTM.

\subsection{Lifting arrangement and stacking}

The lifting requirement of a PCP panel is one of the major differences between PCP and CIP pavement. The lifting of PCP panels cannot be performed from the side of the panel as it is done for building panels, as that would obstruct the placement of the adjacent panels. The position of the lifting point has to be from the top surface of the panel. The lifting position has a significant influence on the moments generated in the panel. The moments generated due to lifting have been plotted and details regarding concrete strength at which the panels may be lifted has also been studied and it has been clarified that the top and bottom moment is optimum for panel lifted at $L / 4$ from the edge (Bly et al., 2013). The points from which the panels are to be lifted should also be used for the stacking of the panels. In case of any misalignment while stacking the panels, a considerable increase in stress can be observed (Bly et al., 2013). Different types of commercially available lifting systems can be used if found feasible (Halfen, 2003). In the developing countries if the lifting arrangements are not commercially available, then we can consider using welded LTM wherein the lifting operation is performed from the edges and stresses are generated at the bottom face of the panel. Thus, it would be necessary to provide appropriate reinforcement at the bottom face of the panel. This lifting arrangement is easy to cast, execute and it can also be used for the purpose of panel levelling.

\subsection{Transportation}

Transportation can be a major factor contributing to the budget of the project. It is important to decide on the size of the panel so that it is easy to transport and no additional permissions are required for it in accordance with the respective legislation. It is most convenient if a suitable precast yard is available in the vicinity. Otherwise, portable prestressing bed and similar such arrangements can be made (Syed \& Sonparote, n. d.). The position of the panels while stacking them on the transporting vehicle is as important as while they are stacked in the yard. 


\subsection{Base preparation method (BPM)}

PCP has a perfectly fabricated base that generally does not match with the top surface of the base course. Hence, while placing the PCP panels, utmost care should be taken to ensure that there is uniform load transfer from the panel to the base course. Any irregularity in this contact leads to stress concentration in the precast slab at the point of contact. The behaviour of PCP to varying soil condition has been analysed and useful design charts have been presented by J. W. Bull (1986). BPM for different soil conditions is different and has been explained below.

\subsubsection{Soft soil condition}

At Ancol Bridge, micro piles have been used to support the PCP slab and to avoid excessive deflections (Figure 15) (Nurjaman, Faizal, Suaryana, \& Hariandja, 2017). Modie slab is another technology developed in Netherlands as part of the "Roads to the Future" program. The structure consists of full-width precast concrete slabs that are

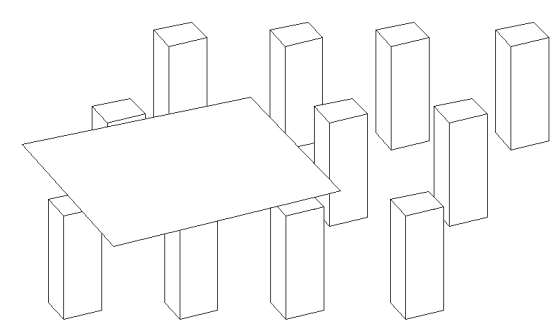

Figure 15. Concrete mattress with micro piles for sub-base improvement

connected to underlying precast reinforced concrete crossbeams with prestressed anchors and sliding planes; no dowel bars are present (Figure 16) (Tayabji, 2010). Analysis of the vertical connector that connects the slab panel to the beams has been performed in details and standards related to it have been drafted (Park, Kim, Jeong, Song, \& Lee, 2015).

\subsubsection{Medium or hard soil condition}

For medium or hard soil conditions, the base course preparation for PCP is similar to CIP Pavement. The base course can be prepared by laying dry lean concrete (DLC) and obtaining the required modulus of subgrade reaction, but additional levelling treatment is required for 

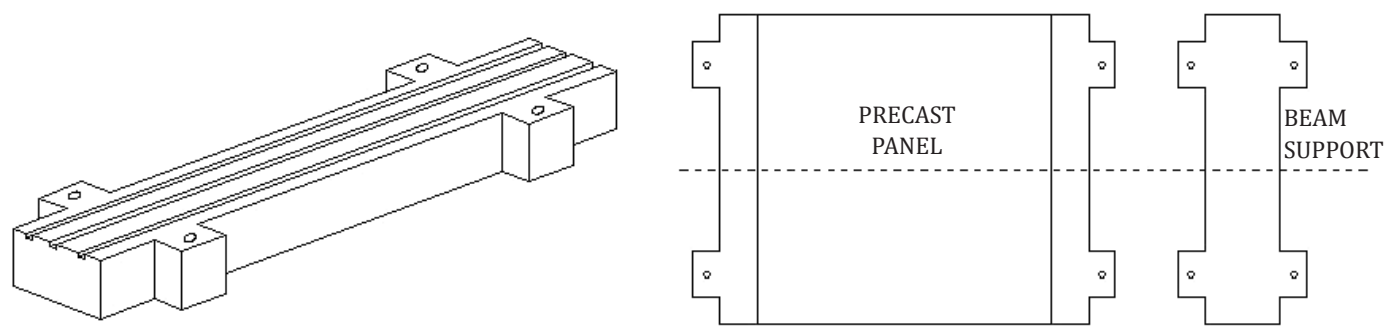

Figure 16. Modie slab

PCP. Depending on the type of PCP being constructed and the expected traffic, the BPM required significant changes (Tayabji \& Wouter, 2015). Types of BPM developed for PCP are:

a. Polyurethane foam

Polyurethane foam has the ability to swell up and lift the concrete panel up to the desired level. Additionally, the swelling of the foam fills up any gaps beneath the panel (Tayabji, 2014; Thrasher, n. d.). However, care is needed to ensure that excessive foam is not inserted beneath the panel, as that would lead to the raising of the panel above the required level. The cost of this method is considerably high and extreme precision and expert guidance is required to execute this method.

b. Flowable fill

Flowable fill has been utilized for multiple repair applications (Buch, 2007), wherein a cementitious material with high viscosity is allowed to flow at the repair location. This fill is such that it flows freely under gravity and fills up any gaps or undulation on the surface and provides a smooth levelled surface by the virtue of its workability. Once the area is filled up to the required level, the panels are placed on top of the fill. This method is difficult to use for continuous construction as the flowable fill needs to be restricted from all four sides so that it rises to the required level.

c. Granular bed

The USSR was the first to make use of a sand bed for providing uniform support to the precast panels (Sapozhnikov \& Rollings, 2007). This method provides a suitable base for the panels, but is tedious to execute. The panels have to be placed and lifted multiple times to ensure base uniformity. As a further development, the panels may be vibrated after being placed on the bed thereby reducing the number of times the panels are to be lifted. Extreme care is needed to avoid any gap between the sand and the panel. Additionally, it is necessary to ensure that the sand/granular material does not erode. 
d. Flowable grout

The precast panels are provided with bedding grout ports through which the grout material is inserted (pressurized or gravitational grout) under the panel. This allows the grout material to flow beneath the panel and fill up the voids between the panel and the base course. In this method, a suitable gap needs to be left intentionally between the base course and the panel so that the flow of grout is not obstructed. This method is costlier than the previous methods but is very effective as it covers any gap. It is suitable for both repairs and continuous constriction. Studies have showed that the use of flowable grout as a BPM has reduced panel deflections (White, Vennapusa, \& Zhang, 2016).

If a project is being constructed in soft soil conditions, it is preferable to take up Modieslab system, even though it is a costly process, as it is extensively tried and tested. For a project undertaken in medium to hard soil conditions, the base preparation would be same as that required for CIP pavement. The only addition would be that of the levelling course in the form of any of the four above stated BPM. Flowable fill is easy to use for repair applications; it ensures the uniformity of the base. For new construction, both flowable grout and polyurethane foam can be used based upon the expertise available and the costs of both methods.

\subsection{Other aspects}

The texturing on the panels can be performed using a texture comb like CIP pavement or by casting the panel in a reverse manner and making the texture using the mould depending on the accurate casting facilities available. Nonetheless, maintaining the riding quality is difficult due to the frequent joints between the panels. However, it can be improved using levelling screws that ensure a uniform road surface. This can also be improved by blacktopping wherever needed, but it is a costly process.

Curves in the road alignment require a carefully graded base course. The best solution is to provide the base layer of dry lean concrete or lean concrete at the required superelevation. Super Slab system has a provision for wrapped panel for smooth transmission from straight road to the curve. Alternatively, smaller sized panels can be fabricated that can take up the required shape.

\section{Future scope}

The development of an easy and standardized design procedure is a primary condition for the fast development and acceptance of this technology. This technology is rather young and multiple attempts have 
been made to further develop this technology by adding innovative Concrete Pavement aspects to it, such as:

1) Pervious PCP: A vast area is covered by the pavement and these panels can help in improving the groundwater table owing to their pervious nature. Additionally, in order to increase the strength of the pervious concrete, fibre reinforced pervious concrete may be used for this purpose (Li, Zhang, Liu, \& Peng, 2017);

2) Hydronic Heated PCP: Heated fluid is circulated through pipes embedded in the PCP panels that helps avoid snow formation. They can also be used for airstrips, thereby making the airstrip usable even in cold climatic conditions (Abdualla et al., 2018);

3) Battery Charging Roadways: Plug-in charging is generally provided for most of the electric cars, this limits their travel distances. Dynamic charging can reduce the parked charging time as well as the size of the battery. PCP can provide an excellent solution to these problems by providing charging pavement panels (Smith \& Snyder, 2016);

4) Power generating PCP: Solar energy harvesting farms require acres of costly land exclusively for that purpose. Recently there have been some efforts in the development of solar energy harvesting roadways. This technology can be further enhanced by the addition of PCP technology as that would facilitate the process of maintenance of such roadways and help reduce the cost of this type of roadways (Shekhar et al., 2018).

The PCP technology requires a lot of improvements. Firstly, a standardised design procedure is highly required to obtain better understanding of this technology by the practicing engineers. Secondly, a set of guidelines is required to ensure smooth and efficient execution and quality check of any future PCP implementation. Thirdly, a simple and effective method needs to be devised for base preparation and inter panel load transfer as all available methods, although effective, are complicated and need an expert to execute.

\section{Conclusion}

PCP technology has gained high popularity owing to its durability and fast construction capabilities. This paper has discussed different applications of PCP developed and executed worldwide. It has further provided a brief discussion of critical aspects of the technology. Suitability of different PCP features for different situations has been identified for the needs of practicing engineers. The paper has further reflected on the innovative concepts developed around this technology and its future scope. 


\section{Acknowledgements}

We would like to thank Visvesvaraya National Institute of Technology for providing us the access to information required for the development of this paper.

\section{REFERENCES}

Abdualla, H., Ceylan, H., Kim, S., Taylor, P. C., Gopalakrishnan, K., \& Kristen, C. (2018). Hydronic Heated Pavement System Using Precast Concrete Pavement for Airport Applications. In Proceedings of International Conference on Transportation and Development 2, 16-24. https://doi.org/10.1061/9780784481554.003

Alwehaidah, N. M., \& Russell, B. W. (2018). Finite Element Analysis and Load Tests of Full-Scale, Variable-Thickness Precast, Prestressed Concrete Pavement on Granular Base. PCI Journal, 63(4), 54-61.

Anderson, K. W., Pierce, L. M., \& Uhlmeyer, J. S. (2007). URETEK Stitch-In-Time ® Gravelly Lake to Puyallup River Bridge. Washington Department of Transport, Washington.

Ashtiani, R. S., \& Haro, G. De. (2014). Performance Determination of Precast Concrete Slabs Used for the Repair of Rigid Pavements. Texas Department of Transport, Texas.

Barnett, G. D. (1980). Prestressed Concrete Roadway. U.S. Patent No. 4,191,490.

Bly, P. G., Priddy, L. P., Jackson, C. J., \& Mason, Q. S. (2013). Evaluation of Precast Panels for Airfield Pavement Repair. Phase 1: System Optimization and Test Section Construction. Engineer Research and Development Center Vicksburg Ms Geotechnical and Structures Lab., US Army Corps of Engineers. https://doi.org/10.21236/ADA582186

Brabston, W. N. (1984). Bomb Damage Repair Precast Slab Design. U.S. Army Engineer Waterways Experiment Station, USA.

Buch, N. (2007). Precast Concrete Panel Systems for Full-Depth Pavement Repairs Field Trials. Federal Highway Administration, USA.

Bull, J. W. (1986). An Analytical Solution To the Design of Precast Concrete Pavements. International Journal For Numerical And Analytical Methods In Geomechanics, 10(2), 115-123. https://doi.org/10.1002/nag.1610100202

Bull, J. W. (1991). Precast Concrete Raft Units. Precast Concrete Raft Units. Boston, MA: Springer. https://doi.org/10.1007/978-1-4615-2644-5

Burnham, T. R. (2007). Precast Concrete Pavement Panels on Minnesota Trunk Highway 62 - First Year Performance Report. Minnesota Department of Transportation, USA.

Cable, N. D., McCullough, B. F., \& Burns, N. H. (1985). New Concepts in Prestressed Concrete Pavement. Transportation Research Record. 
Chen, Y. S., Murrell, S. D., \& Larrazabal, E. (2004). Precast Concrete (PC) Pavement Test on Taxiway D-D at Laguardia Airport. In Proceedings of Airfield Pavements Specialty Conference 2003 (pp. 447-482). https://doi.org/10.1061/40711(141)30

Chen, Y., \& Chang, L. M. (2015). Paving for the Future - Precast Prestressed Concrete Pavement (PPCP). Scientific Cooperations Journal of Civil Engineering and Architecture, 1(1), 7-12.

Daigle, J. P. (1974). Interlocking Precast Concrete Slabs. USP 3,842,562.

DeWitt, G. L. (2006). Precast Concrete Paving Panels: The Colorado Department of Transportation Region 4 Experience, 2000 to 2006. Denver. Colorado Department of Transportation, USA.

Enriquez, M. M., Pabuna, L. M. F., \& Sawali, F. K. A. (2013). Applicability of Precast Reinforced Concrete Pavement on the Proposed EDSA Rehabilitation. Mapua Institute of Technology, Manila City, Philipense.

Fort Miller. (n. d.). https://www.super-slab.com/.

Fugro Consultants. (2012). Final Report Proposed Process For Design Of Precast Concrete Pavements Sacramento, California. California Department of Transportation.

Gaudelli, E. N., \& Shepler, E. E. (1987). Apparatus And Procedure For Forming Pre-Shaped Interlocking Cement Slabs. USP 4 660,344.

Gopalaratnam, V. S., Donahue, J., Davis, B., \& Dailey, C. (2006). Precast Prestressed Panels for Rapid Full-Depth Pavement Repairs. In Proceedings of the Structures Congress and Exposition (pp. 155). 2006. https://doi.org/10.1061/40889(201)155

Green, M. L. (1983). Portable Roadway. U.S. Patent No. 4,376,596.

Halfen. (2003). Precast Lifting and Fixing Systems. Retrieved from http:// downloads.halfen.com/catalogues/uk/media/catalogues/liftingsystems/ Threaded_lifting_systems-uk.pdf

Hara, C., Takuya, I., Matsuno, S., and Nishizawa, T. (1997). Long Term Performance of Prestressed Concrete Pavements in Japan. In Proceedings of Purdue Conference on Concrete. Indiana, USA.

Hargett, E. R. (1986). Field Study of Performance and Cost of a Composite Pavement Consisting of Prestressed Concrete Panels Interconnected and Covered With Asphaltic Concrete. Highway Research Record Number 239, Highway Research Board, 137-149.

Klunker, F. (1981). Status and Developments in the Construction of Prestressed Concrete Runways in European Airports. In Proceedings of 2nd International Conference on Concrete Pavement Design. Purdue University, West Lafayette, Indiana.

Kohler, E., Smith, P. J., Harvey, J., \& Pyle, T. (2007). Precast Concrete Pavements and Results of Accelerated Traffic Load Test. In Proceedings of International Conference on Optimizing Paving Concrete Mixtures and Accelerated Concrete Pavement Construction and Rehabilitation (pp. 263-281).

Kumakura, M., Kondo, S., Kai, K., Abe, Y., \& Sato, R. (1994). Development of a Prestressing Method for Joints of Precast Prestressed Concrete Pavement Slabs. In Proceedings of International Symposium on Concrete Roads (pp. 83-88). 
Lane, B., \& Kazmierowski, T. (2007). Short Term Performance of Innovative Precast Concrete Slab Repairs on Highway 427, Toronto. In Annual Conference of the Transporation Association of Canada. Saskatoon.

Larrard, F., Sedran, T., \& Balay, J.-M. (2013). Removable Urban Pavements: An Innovative, Sustainable Technology. International Journal of Pavement Engineering, 14(1), 1-11. https://doi.org/10.1080/10298436.2011.634912

Lee, H. J. (2004). Prefabricated Cement Concrete Slab for Road Pavement. U.S. Patent No. 6,688,808 B2.

Li, J., Zhang, Y., Liu, G., \& Peng, X. (2017). Preparation and Performance Evaluation of an Innovative Pervious Concrete Pavement. Construction and Building Materials, 138, 479-485. https://doi.org/10.1016/j.conbuildmat.2017.01.137

Merritt, D. K., McCullough, B. F., \& Burns, N. H. (2002). Construction and Preliminary Monitoring of the Georgetown, Texas Precast Prestressed Concrete Pavement. Report No. FHWA A/TX-03-1517-01-IMP-1 (Vol. 7). Retrieved from http://ctr.utexas.edu/wp-content/uploads/pubs/5_1517_1.pdf

Merritt, D. K., McCullough, B. F., \& Burns, N. H. (2005). Design-Construction of a Precast, Prestressed Concrete Pavement for Interstate 10, El Monte, California. PCI Journal, 50(2), 18-27. https://doi.org/10.15554/pcij.03012005.18.27

Merritt, D. K., Miron, A. J., Rogers, R. B., \& Rasmussen, R. O. (2007). Construction of the Iowa Highway 60 Precast Prestressed Concrete Pavement Bridge Approach Slab Demonstration Project. Iowa Department of Transportation, USA.

Merritt, D. K., Rogers, R., \& Rasmussen, R. (2008). Construction of a Precast Prestressed Concrete Pavement Demonstration Project on Interstate 57 Near Sikeston, Missouri. U.S. Department of Transportation. Washington.

Merritt, D., McCullough, B., \& Burns, N. (2001). Feasibility of Using Precast Concrete Panels to Expedite Construction of Portland Cement Concrete Pavements. Transportation Research Record, 1761(1), 3-9. https://doi.org/10.3141/1761-01

Meyer, A. H., McCullough, B. F., \& Fowler, D. W. (1981). Polymer Concrete for Precast Repair of Continuously Reinforced Concrete Pavement on IH 30, Near Mt. Pleasant. Texas Department of Transportation, USA.

Nantung, T., Firmansjah, J., Suwarto, E., \& Hidayat, H. M. (2010). Design and Construction of Precast Prestressed Concrete Pavement in Indonesia. In Transportation Research Board 89th Annual Meeting.

Nurjaman, H., Faizal, L., Suaryana, N., \& Hariandja, B. (2017). Design, Development, and Application of Precast and Prestressed Concrete System for Rigid Pavement in Indonesia. In Proceedings of 3rd International Conference on Construction and Building Engineering. American Institute of Physics. https://doi.org/10.1063/1.5011510

Olidis, C., Swan, D. J., \& Saeed, A. (2010). Precast Slab Literature Review Report: Repair of Rigid Airfield Pavements Using Precast Concrete Panels-A state-of-the-Art Review. Air Force Research Laboratory. https://doi.org/10.21236/ADA546971

Park, S. B., Kim, W. S., Jeong, Y., Song, J. J., \& Lee, S. Y. (2015). Development and Performance of a Movable Smart Vertical Connector in a Modular Roadway Slab. Scientia Iranica, 22(6), 2118-2125. 
Priddy, L. P. (2015). Evaluation of Precast Portland Cement Concrete Panels for Airfield Pavement Repairs. Geotechnical and Structures Laboratory. US Army Corps of Engineers.

Priddy, L. P., Bly, P. G., \& Flintsch, G. W. (2013). Review Of Precast Portland Cement Concrete Panel Technologies For Use In Expedient Portland Cement Concrete Airfield Pavement Repairs. Transportation Research Record: Journal of the Transportation Research Board, 1-20.

Qu, B., Weng, X.-z., Zhang, J., Mei, J.-j., Guo, T.-x., Li, R.-f., \& An, S.-h. (2017). Analysis on the Deflection and Load Transfer Capacity of a Prefabricated Airport Prestressed Concrete Pavement. Construction and Building Materials, 157, 449-458. https://doi.org/10.1016/j.conbuildmat.2017.09.124

Rao, C., Sadasivam, S., Littleton, P., Ullman, G., \& Mallela, J. (2012). Virginia I-66 Concrete Pavement Replacement Using Precast Concrete Pavement Systems. Retrieved from http://trid.trb.org/view.aspx?id=1143806

Reese, R. W., \& Keech, S. W. (1992). Method And Article Of Manufacture For Removable Pavement For Underground Utility Placement. U.S. Patent No. 5,098,218.

Rollings, R. S., \& Chou, Y. T. (1981). Precast Concrete Pavements. US Army Corps of Engineers. https://doi.org/10.21236/ADA108802

Roman Stone Construction Company. (n. d.). https://www.romanstoneco.com/

Sapozhnikov, N., \& Rollings, R. (2007). Soviet Precast Prestressed Construction for Airfields. In Proceedings of 2007 FAA Worldwide Airport Technology Transfer Conference (p. 11). Atlantic City.

Sato, K., Fukute, T., \& Inukai, H. (1981). Some New Construction Methods for Prestressed Concrete Airport Pavements. In 2nd International Conference on Concrete Paving Design (pp. 149-159). Purdue University, West Lafayette.

Sharma, A. K. (1990). Experimental Rehabilitation of Jointed Portland Cement Concrete Pavement. In Proceedings of Transportation Research Record 1272 (pp. 27-34).

Shekhar, A., Kumaravel, V. K., Klerks, S., De Wit, S., Venugopal, P., Narayan, N., Zeman, M. (2018). Harvesting Roadway Solar Energy-Performance of The Installed Infrastructure Integrated PV Bike Path. IEEE Journal of Photovoltaics, 8(4), 1066-1073. https://doi.org/10.1109/JPHOTOV.2018.2820998

Simonsen, J. E. (1971). Progress Report Concrete Pavement Joint Repair With Pre-Cast Slab.

Smith, P. J. (2003). Method of Forming, Installing and a System for Attaching a pre Fabricated Pavement Slab to a Subbase and the Pre-Fabricated Pavement Slab so Formed. U.S. Patent No. 6,607,329 B2.

Smith, P., \& Snyder, M. B. (2016). Manual for Jointed Precast Concrete Pavement. National Precast Concrete Association.

Syed, A., \& Sonaprote, R. (2019). Development and Early age Performance of an innovative Prestressed Precast Concrete Pavement. Journal of Construction Engineering and Management, 146(2), 1-9. https://doi.org/10.1061/(ASCE)C0.1943-7862.0001741

Syed, A., \& Sonparote, R. S. (2017). Analysis of Prestressed Precast Concrete Pavement. Materials Today: Proceedings, 4(9), 9713-9717. https://doi.org/10.1016/j.matpr.2017.06.253 
Syed, A., \& Sonparote, R. S. (n. d.). Development of a Self Supported Portable Pre-Tensioning System for Slab Panels. In Proceedings of Advances in Construction Technology and Management. VNIT, Nagpur, 21-23 January 2016.

Tawfiq, K., \& Armaghani, J. (2016). Accelerated Slab Replacement Using Temporary Precast Panels and Self-Consolidating Concrete. Florida Department of Transportation, USA.

Tayabji, S. (2001). Prestressed Concrete Pavement Technology Update. In Proceedings of 7 th International Conference on Concrete Pavements. USA, Florida, Orlando, 9-13 September 2001.

Tayabji, S. (2010). Precast Concrete Pavement Technology Desk Scan. Retrieved from http://www.precastconcretepavement.org/TechnologyPresentations/ PPCP65\%20Desk\%20Scan\%20(PCPS)\%20(26Nov2010).pdf

Tayabji, S. (2014). Precast Concrete Pavement Innovations, Performance and Best Practices. In Proceedings of 12th International Symposium on Concrete Roads. Czech Republic, Prague.

Tayabji, S., Buch, N., \& Ye, D. (2011). Performance of Precast Concrete Pavements. Transportation and Development Institute Congress 2011. https://doi.org/10.1061/41167(398)86

Tayabji, S., Buch, N., \& Kohler, E. (2008). Precast Concrete pavements - Current Technology and Future Directions. In Proceedings of 9th International Conference on Concrete Pavements. San Francisco. Retrieved from https:// trid.trb.org/view.aspx?id=1263154

Tayabji, S., Dan, Y., \& Neeraj, B. (2013). Precast Concrete Pavement Technology. SHRP 2, US Department of Transportation, Washington, USA.

Tayabji, S., \& Brink, W. (2015). Precast Concrete Pavement Bedding Support Systems. FHWA Tech Brief. https://doi.org/10.13140/RG.2.1.2238.3441

Thrasher. (n. d.). https://www.gothrasher.com/commercial/pavement-liftingstabilization/

Tsuji, T. (1996). Joint Structure for Coupling Precast Concrete Pavement Slabs. U.S. Patent No. 5,586,834.

Tyson, S., \& Tayabji, S. (2009). Precast Prestressed Concrete Pavement for Reconstruction and Rehabilitation of Existing Pavements. FHWA Tech Brief, 8.

Ulislam, A. (2014). Pavement Slabs With Sliding Dowels. U.S. Patent No. 8,911,173 B2.

Uretek. (n. d.). http://uretekusa.com

Vaitkus, A., Gražulytė, J., Kleizienė, R., Vorobjovas, V., \& Šernas, O. (2019). Concrete Modular Pavements - Types, Issues and Challenges. Baltic Journal of Road and Bridge Engineering, 14(1), 80-103. https://doi.org/10.7250/bjrbe.2019-14.434

Vaitkus, A., Kleizienė, R., Vorobjovas, V., \& Čygas, D. (2019). Mixture Strength Class and Slab Dimensions' Effect on The Precast Concrete Pavement Structural Performance. The Baltic Journal of Road and Bridge Engineering, 14(3), 443-471. https://doi.org/10.7250/bjrbe.2019-14.452 
White, D. J., Vennapusa, P., \& Zhang. (2016). Improving the Foundation Layers for Concrete Pavement Concrete Pavements Jointed Concrete Pavement Rehabilitation With Precast Concrete Pavement - California I-15 Field Study.

Yee, A. A. (2006). Precast Concrete Slab Systemand Method Therefor. U.S. Patent No. 7,134,805 B2.

Yeoman, R. C. (1957). Method of Laying Prefabricated Slabs. U.S. Patent No. $2,780,150$. 